\title{
Improvement of the UV Barrier and Antibacterial Properties of Crosslinked Pectin/Zinc Oxide Bionanocomposite Films
}

\author{
Karina Dyasti Hari ${ }^{1}$ (D), Coralia V. Garcia ${ }^{1}$, Gye-Hwa Shin ${ }^{2}$ and Jun-Tae Kim ${ }^{1, * D}$ \\ 1 Department of Food Science and Technology, Keimyung University, Daegu 42601, Korea; \\ karina.dyastihari@gmail.com (K.D.H.); cvalentinag@yandex.com (C.V.G.) \\ 2 Department of Food and Nutrition, Kunsan National University, Gunsan 54150, Korea; \\ winnie19@kunsan.ac.kr \\ * Correspondence: jtkim92@kmu.ac.kr
}

Citation: Hari, K.D.; Garcia, C.V.; Shin, G.-H.; Kim, J.-T. Improvement of the UV Barrier and Antibacterial Properties of Crosslinked Pectin/Zinc Oxide Bionanocomposite Films. Polymers 2021, 13, 2403. https:// doi.org/10.3390/polym13152403

Academic Editor: Evgenia

G. Korzhikova-Vlakh

Received: 2 July 2021

Accepted: 19 July 2021

Published: 22 July 2021

Publisher's Note: MDPI stays neutral with regard to jurisdictional claims in published maps and institutional affiliations.

Copyright: (C) 2021 by the authors. Licensee MDPI, Basel, Switzerland. This article is an open access article distributed under the terms and conditions of the Creative Commons Attribution (CC BY) license (https:// creativecommons.org/licenses/by/ $4.0 /)$

\begin{abstract}
Pectin-based antibacterial bionanocomposite films were prepared by crosslinking with calcium chloride $\left(\mathrm{CaCl}_{2}\right)$ and mixing with zinc oxide nanoparticles (ZnO-NPs) at various concentrations $\left(0.5 \%, 1 \%\right.$, and $1.5 \% w / w$, based on pectin). Crosslinking with $1 \% \mathrm{CaCl}_{2}$ significantly $(p<0.05)$ improved the tensile strength of the pectin films, although their elongation at break was decreased. The UV-light barrier property of the pectin/ZnO bionanocomposite films was significantly $(p<0.05)$ improved with increasing ZnO-NP concentrations. In addition, the bionanocomposite films incorporating 1.5\% ZnO-NPs showed excellent antibacterial effects against both Escherichia coli and Staphylococcus aureus, inhibiting over 99\% of the bacteria. Therefore, the developed crosslinked pectin/ ZnO bionanocomposite films show great potential as active packaging materials with excellent UV-blocking and antibacterial properties.
\end{abstract}

Keywords: antibacterial; bionanocomposite; pectin; zinc oxide; crosslinking

\section{Introduction}

In recent years, antimicrobial packaging has attracted a great deal of attention from the food industry because of the increase in the consumer demand for chemical preservativefree products [1]. Moreover, there is growing interest in biodegradable packaging as an eco-friendly replacement for petroleum-based polymers. As abundant, renewable, environmentally friendly, and sustainable materials, biopolymers have been used to fabricate biodegradable plastics and edible films [2,3]. Among biopolymers, polysaccharides are attractive materials because of their good film-forming properties, sustainability, and abundance $[4,5]$.

Pectin is the major structural component of the plant cell wall and is one of the largest constituents in citrus by-products. This polysaccharide is generally recognized as safe (GRAS) by the United States Food and Drug Administration (FDA), and is used in food processing, mostly as a gelling, stabilizing, or thickening agent in products such as jams, yogurt, fruit drinks, and ice cream [6]. Pectin is mainly composed of galacturonic acid units. Depending on its degree of esterification (DE), pectin can be classified as high methoxyl pectin ( $\mathrm{DE}>50 \%$ ) and low methoxyl pectin ( $\mathrm{DE}<50 \%$ ), with both being able to be used for film formation [7]. Some of the advantages of pectin edible films are biocompatibility, biodegradability, and non-toxicity [8]. Nevertheless, neat pectin films do not show satisfactory functionality because of their high hydrophilicity, poor mechanical and barrier properties, and low water resistance $[9,10]$. Hence, various strategies have been tested for improving the properties of pectin-based films, including crosslinking, blending with other polymers, and incorporating nanoparticles and essential oil nanoemulsions $[7,10]$. Such films can also be engineered to exhibit functionalities. For instance, pectin films incorporating silica nanoparticles extended the shelf life of strawberries, and pectin/corn flour/beetroot powder films extended the shelf life of tomatoes [11,12]. Pectin 
films incorporating lime antioxidants hindered soybean oil oxidation [13]. Films made of a combination of pectin and hydrocolloids from chia seeds showed antioxidant properties, and electrospun pectin films were used in multilayer structures with aroma barrier properties [14,15]. Moreover, pectin films incorporating $\mathrm{ZnO}$ nanoparticles (ZnO-NPs) were reported to show enhanced strength and water barrier properties as well as antimicrobial effects [9].

Compared with neat pectin films, crosslinked pectin films exhibit increased tensile strength and water resistance [16]. The crosslinking mechanism of pectin with divalent metal ions such as $\mathrm{Ca}^{2+}$ and $\mathrm{Zn}^{2+}$ is explained by the "egg-box" model, in which the crosslinks are formed by divalent ions occupying electronegative cavities in the ribbon structure of carboxylic groups [17]. Hence, the functional and mechanical properties of pectin films could be improved by incorporating both calcium ions and ZnO-NPs.

ZnO-NPs exhibit advantages such as non-toxicity, availability, low cost, high ultraviolet absorption capacity, and strong antimicrobial activity $[18,19]$. Compared to other natural antibacterial materials such as nisin, essential oils, grapefruit seed extract (GFSE), etc., $\mathrm{ZnO}-\mathrm{NPs}$ have high thermal stability and do not lose their antibacterial activity during the processing of most food packaging films such as polyethylene (PE), polypropylene (PP), polyethylene terephthalate (PET), etc. It is thought that the antimicrobial activity of $\mathrm{ZnO}-\mathrm{NPs}$ is dependent on the release of $\mathrm{Zn}^{+2}$ ions and the formation of reactive oxygen species (ROS), which damage the integrity of the microbial cells [20]. $\mathrm{ZnO}$ is recognized as a GRAS substance by the FDA, although no differentiation is made between the bulk and nano form. Moreover, ZnO-NPs are approved for certain food contact applications in the European Union [21].

Therefore, here, we aimed to optimize the development of crosslinked pectin-based films incorporating $\mathrm{ZnO}-\mathrm{NPs}$. The effects of calcium chloride and $\mathrm{ZnO}-\mathrm{NP}$ concentration on the mechanical, physical, optical, UV barrier, and antibacterial ability of the bionanocomposite films were evaluated. In particular, the goal of this study was to produce bionanocomposite films with enhanced UV-blocking and antibacterial properties.

\section{Materials and Methods}

\subsection{Materials}

Pectin powder from citrus was purchased from Daejung Chemicals \& Metals Co., Ltd. (Siheung, Korea). Glycerol was obtained from Duksan Pure Chemicals Co., Ltd. (Ansan, Korea). Calcium chloride $\left(\mathrm{CaCl}_{2}\right)$ and $\mathrm{ZnO}$ nanopowder were purchased from Sigma Aldrich Chemicals (St. Louis, MO, USA). Nutrient broth (NB) was purchased from DB Difco $^{\mathrm{TM}}$ (Sparks, MD, USA). Escherichia coli ATCC 8739 and Staphylococcus aureus ATCC $6538 \mathrm{P}$ were procured from the American Type Culture Collection (ATCC).

\subsection{Film Preparation}

\subsubsection{Crosslinked Pectin Films}

To prepare crosslinked pectin films (CPF), $4 \mathrm{~g}$ of pectin was dissolved in $170 \mathrm{~mL}$ of distilled water. As a plasticizer, glycerol was added at $20 \%(w / w$, based on pectin) to prevent brittleness. Then, a $\mathrm{CaCl}_{2}$ solution $(30 \mathrm{~mL} ; 0.5 \%, 1 \%, 2 \%$, and $5 \% \mathrm{w} / \mathrm{v}$ ) was added to the pectin solution and mixed using a magnetic stirrer at $70{ }^{\circ} \mathrm{C}$ for $20 \mathrm{~min}$. The film-forming solution was cooled down at room temperature for $30 \mathrm{~min}$ before casting it onto a Teflon-coated glass plate $(13.5 \mathrm{~cm} \times 25 \mathrm{~cm})$ and drying at $30^{\circ} \mathrm{C}$ in a convection oven for $48 \mathrm{~h}$. The fully dried pectin films were conditioned at $25^{\circ} \mathrm{C}$ and $50 \%$ relative humidity $(\mathrm{RH})$ for $48 \mathrm{~h}$ before testing their mechanical properties.

\subsubsection{Crosslinked Pectin/ZnO Bionanocomposite Films}

For the preparation of crosslinked pectin/ZnO bionanocomposite films (CPZBF), a $\mathrm{ZnO}-\mathrm{NP}$ dispersion was prepared by adding $\mathrm{ZnO}$ nanopowder $(0.5 \%, 1 \%$, and $1.5 \%$, $w / w$, based on pectin) to $170 \mathrm{~mL}$ of distilled water containing $20 \%(w / w)$ glycerol, followed by ultrasonication at $40 \%$ amplitude for $10 \mathrm{~min}$. $4 \mathrm{~g}$ of pectin was dissolved in the homoge- 
neous dispersion of $\mathrm{ZnO}-\mathrm{NPs}$ and stirred at room temperature for $3 \mathrm{~h}$. Then, $30 \mathrm{~mL}$ of a $\mathrm{CaCl}_{2}$ solution ( $1 \% w / w$, based on pectin) was added and mixed using a magnetic stirrer at $70{ }^{\circ} \mathrm{C}$ for $20 \mathrm{~min}$. The film-forming solution was cooled down at room temperature for $30 \mathrm{~min}$ before casting it onto the Teflon-coated glass plate $(13.5 \mathrm{~cm} \times 25 \mathrm{~cm})$ and dried as described in Section 2.2.1.

\subsection{Characterization of Bionanocomposite Films}

\subsubsection{Optical Properties}

The color of the CPZBF was determined using a Chroma Meter (CR-400, Minolta, Tokyo, Japan). A white color standard plate $\left(L^{*}=96.76, a^{*}=0.05, b^{*}=1.94\right)$ was used as a background. The total color difference $(\Delta E)$ was calculated using Equation (1)

$$
\Delta E=\sqrt{(\Delta L)^{2}+(\Delta a)^{2}+(\Delta b)^{2}}
$$

where $\Delta L, \Delta a$, and $\Delta b$ represent the differences in lightness ( $L$ ), redness (a), and yellowness (b) values of the control (crosslinked pectin film) and CPZBF samples. At least five points were measured for the color parameters for each film, and the average values were used.

The UV absorbance of the CPZBF was measured using a UV-visible spectrophotometer (UV-2600, Shimadzu, Kyoto, Japan) at wavelengths of 200-550 nm.

\subsubsection{Mechanical Properties}

The bionanocomposite films were cut into $10 \mathrm{~mm} \times 10 \mathrm{~mm}$ strips and conditioned at $25{ }^{\circ} \mathrm{C}$ and $50 \%$ RH for $48 \mathrm{~h}$ before their mechanical test. Film thickness was measured in five random locations in each sample using a micro-caliper (MDC-25MJ, Mitutoyo Co., Kanagawa, Japan), and the average was calculated. Tensile strength, elongation at break, and Young's modulus of the films were tested using a Universal Testing Machine (UTM; Zwick 2010TN, Zwick GmbH \& Co. KG, Ulm, Germany) according to the standard method of ASTM D882-12 [22].

\subsubsection{Moisture Content}

To determine the water content, the crosslinked pectin films were cut into $2 \mathrm{~cm} \times 2 \mathrm{~cm}$ squares and weighed $\left(W_{1}\right)$. The water content of the films was determined by drying the film samples in a convection oven at $105^{\circ} \mathrm{C}$ for $24 \mathrm{~h}$, and weighing again $\left(W_{2}\right)$ after cooling them to room temperature. The moisture content was calculated using Equation (2):

$$
\text { Moisture content }(\%)=\frac{W_{1}-W_{2}}{W_{1}} \times 100
$$

\subsubsection{Water Solubility}

Water solubility was determined using a previously published method with slight modifications [23]. Film samples $(2 \mathrm{~cm} \times 2 \mathrm{~cm})$ were dried at $105^{\circ} \mathrm{C}$ in a convection oven for $24 \mathrm{~h}$ and weighed $\left(W_{i}\right)$. Then, the film samples were put into flasks $(50 \mathrm{~mL})$ containing $20 \mathrm{~mL}$ distilled water with constant stirring at $25^{\circ} \mathrm{C}$ for $6 \mathrm{~h}$. The liquid was filtered and the remaining film mass was dried at $105^{\circ} \mathrm{C}$ for $24 \mathrm{~h}$ until it showed a constant weight $\left(W_{f}\right)$. Film solubility was calculated using Equation (3)

$$
\text { Film solubility }(\%)=\frac{W_{\mathrm{i}}-W_{\mathrm{f}}}{W_{\mathrm{i}}} \times 100
$$

\subsubsection{Water Vapor Permeability (WVP)}

The water vapor permeability of the films was determined using a modified cup method [24]. Film samples were cut into $6.7 \mathrm{~cm} \times 6.7 \mathrm{~cm}$ squares and covered the cups containing distilled water. Samples were stored in a chamber at $25^{\circ} \mathrm{C}$ and $25 \% \mathrm{RH}$ for 
$12 \mathrm{~h}$. Changes in the weight of the film samples were recorded every $2 \mathrm{~h}$. The water vapor permeability was calculated using Equation (4)

$$
\mathrm{WVP}=\frac{\mathrm{WVTR} \times \delta}{\mathrm{p}_{1}-\mathrm{p}_{2}} \times 100
$$

where WVTR is the water vapor transmission rate, $\delta$ is the film thickness, and $p_{1}$ and $p_{2}$ are the partial pressures of water vapor inside and outside the cup, respectively.

\subsubsection{FTIR Analysis}

The Fourier-transform infrared (FTIR) spectra of the films were recorded using attenuated total reflection Fourier transmission infrared (ATR-FTIR) equipment (Nicolet Is5, Thermo Fisher Scientific, Waltham, MA, USA). The film samples were cut into rectangular strips $(4 \mathrm{~cm} \times 4 \mathrm{~cm})$ and were directly put onto the ATR cell. The spectra were recorded as 64 scans at a $4 \mathrm{~cm}^{-1}$ resolution ranging from 600 to $4000 \mathrm{~cm}^{-1}$ wavenumber.

\subsubsection{Differential Scanning Calorimetry (DCS)}

Thermal properties of the films were evaluated using a DSC 25 (TA Instruments, New Castle, DE, USA) as previously reported, with modifications [25]. Roughly 5-10 mg of each film sample was put in an aluminum pan and heated from 0 to $300^{\circ} \mathrm{C}$ at a constant heating rate of $10{ }^{\circ} \mathrm{C} / \mathrm{min}$ under a nitrogen flow of $50 \mathrm{~mL} / \mathrm{min}$. DSC thermograms were recorded.

\subsubsection{Antibacterial Activity}

The antibacterial activity of the bionanocomposite films was examined against $E$. coli (Gram-negative) and S. aureus (Gram-positive). The antimicrobial test was performed by the plate counting method with slight modifications [18]. S. aureus and E. coli were individually grown on $\mathrm{NB}$ at $37^{\circ} \mathrm{C}$. The sample films were cut into rectangular shapes $(1 \mathrm{~cm} \times 6 \mathrm{~cm})$ and placed in test tubes. Diluted broth $\left(10 \mathrm{~mL}\right.$, around $\left.10^{5} \mathrm{CFU} / \mathrm{mL}\right)$ was poured into a test tube containing a film sample, and incubated at $37^{\circ} \mathrm{C}$ for $24 \mathrm{~h}$. Diluted broth alone was used as the control. After incubation, the cell viability of each bacterium was calculated by counting colonies on the plates, and reporting the values as $\mathrm{CFU} / \mathrm{mL}$. The antibacterial rate was calculated using Equation (5):

$$
\text { Antibacterial rate }(\%)=\frac{(\mathrm{Nc}-\mathrm{Ns})}{\mathrm{Nc}} \times 100
$$

where Nc is the number of viable bacteria on the control film (pure LDPE film) and Ns is the number of viable bacteria on the bionanocomposite films after $24 \mathrm{~h}$ of incubation. The antibacterial activity was calculated as the difference in logarithmic values of viable bacteria between the control film and bionanocomposite films as described in the JIS Z2801:2010 regulation [26].

\subsection{Statistical Analysis}

Experiments were duplicated at least three times, and data are expressed as mean \pm standard deviation (SD). Statistical significance was determined by analysis of variance (ANOVA) and Duncan's multiple range test. The level of significance was set at $p<0.05$ using SPSS version 16 (SPSS Inc., Chicago, IL, USA).

\section{Results and Discussion}

3.1. Characterization of Crosslinked Pectin Films

\subsubsection{Mechanical Properties}

Table 1 shows the effects of $\mathrm{CaCl}_{2}$ concentration on the thickness, tensile strength (TS), Young's modulus (YM), elongation at break (E), moisture content, and water solubility of pure pectin (control) and crosslinked pectin films. Adding $\mathrm{CaCl}_{2}$ increased the thickness of the films as compared to the control film, with the films crosslinked with $1 \% \mathrm{CaCl}_{2}$ having 
a thickness of $101.5 \pm 11.9 \mu \mathrm{m}$ and the control films of $85.1 \pm 8.1 \mu \mathrm{m}$. The TS of pectin film crosslinked with $1 \% \mathrm{CaCl}_{2}(22.7 \pm 1.4 \mathrm{MPa})$ was significantly $(p<0.05)$ higher than that of the control $(14.3 \pm 1.4 \mathrm{MPa})$, although further increases in $\mathrm{CaCl}_{2}$ resulted in a slight but not significant $(p>0.05)$ decrease in TS. On the other hand, crosslinking caused a significant $(p<0.05)$ decrease in the $E$ of the films, with the control and the film crosslinked with $1 \%$ $\mathrm{CaCl}_{2}$ having $E$ values of $8.3 \%$ and $6.1 \%$, respectively. Nevertheless, $E$ was not significantly $(p>0.05)$ changed with further increases in the $\mathrm{CaCl}_{2}$ content.

Table 1. Effect of $\mathrm{CaCl}_{2}$ concentration on the mechanical properties of the crosslinked pectin films (CPF).

\begin{tabular}{|c|c|c|c|c|c|c|}
\hline Sample * & $\begin{array}{c}\text { Thickness } \\
(\mu \mathrm{m})\end{array}$ & $\begin{array}{c}\text { Young's Modulus } \\
\text { (MPa) }\end{array}$ & $\begin{array}{l}\text { Tensile Strength } \\
\text { (MPa) }\end{array}$ & $\begin{array}{c}\text { Elongation at Break } \\
(\%)\end{array}$ & $\begin{array}{c}\text { Moisture Content } \\
(\%)\end{array}$ & $\begin{array}{c}\text { Water Solubility } \\
(\%)\end{array}$ \\
\hline Control & $85.1 \pm 8.1^{\mathrm{a}}$ & $535.8 \pm 54.8^{a}$ & $14.3 \pm 1.4^{\mathrm{a}}$ & $8.3 \pm 1.1^{c}$ & $19.6 \pm 1.9^{b}$ & $51.3 \pm 3.4^{b}$ \\
\hline CPF- $0.5 \%$ & $90.6 \pm 10.3^{a}$ & $721.8 \pm 34.5^{b}$ & $18.3 \pm 1.4^{\mathrm{b}}$ & $7.4 \pm 0.8^{b}$ & $18.3 \pm 0.7^{b}$ & $47.8 \pm 1.0^{\mathrm{b}}$ \\
\hline CPF-1.0\% & $101.5 \pm 11.9^{b}$ & $857.3 \pm 56.5^{c}$ & $22.7 \pm 1.4^{c}$ & $6.1 \pm 1.0^{\mathrm{a}}$ & $14.2 \pm 1.2^{\mathrm{a}}$ & $31.8 \pm 2.8^{a}$ \\
\hline CPF-2.0\% & $93.5 \pm 17.9^{a}$ & $833.2 \pm 121.6^{c}$ & $22.0 \pm 2.5^{c}$ & $5.7 \pm 0.7^{\mathrm{a}}$ & $15.9 \pm 0.7^{\mathrm{a}}$ & $33.4 \pm 0.8^{a}$ \\
\hline CPF-5.0\% & $88.1 \pm 6.4^{\mathrm{a}}$ & $763.3 \pm 95.5^{b}$ & $21.9 \pm 1.4^{c}$ & $5.6 \pm 1.0^{\mathrm{a}}$ & $16.0 \pm 1.3^{a}$ & $32.6 \pm 2.6^{a}$ \\
\hline
\end{tabular}

${ }^{*}$ Concentrations represent $\% \mathrm{CaCl}_{2}$ solution $(w / v)$. Data represent the mean \pm standard deviation. Different letters in the same column indicate significant differences at $p<0.05$ by Duncan's multiple range test.

The increase in TS by the addition of $\mathrm{CaCl}_{2}$ is due to the crosslinking between the carboxyl acid $\left(\mathrm{COO}^{-}\right)$of pectin and calcium ions $\left(\mathrm{Ca}^{2+}\right)$, described in the "egg-box" model $[27,28]$. The multivalent cations penetrate the film matrix and enhance the formation of bonds between the polymer chains, resulting in an increase in TS but also less flexibility and a more rigid polymer structure. Based on the results obtained, the film crosslinked with $1 \% \mathrm{CaCl}_{2}$ was used for further experiments.

\subsubsection{Moisture Content and Water Solubility}

Crosslinking with $\mathrm{CaCl}_{2}$ decreased both the moisture content and water solubility of the pectin films (Table 1). The pure pectin film (control) had 19.6\% $\pm 1.9 \%$ moisture, which significantly $(p<0.05)$ decreased to $14.2 \% \pm 1.2 \%$ after the addition of $1 \% \mathrm{CaCl}_{2}$. Nevertheless, further increases in $\mathrm{CaCl}_{2}$ did not significantly $(p>0.05)$ affect the moisture content. Water solubility showed the same trend, decreasing significantly $(p<0.05)$ from $51.3 \% \pm 3.4 \%$ to $31.8 \% \pm 2.8 \%$ after crosslinking with $1 \% \mathrm{CaCl}_{2} . \mathrm{CaCl}_{2}$-crosslinked pectin resulted in decreased moisture content and water solubility, indicating that the $\mathrm{Ca}^{2+}$ ions promoted greater cohesion of the intermolecular bonds, leaving less available spaces for accommodating water molecules [29]. Crosslinking agents can thus help to overcome the poor moisture resistance of polysaccharide films by decreasing their hydrophilic properties through the formation of bonds between the polysaccharide molecules, reducing water absorption [30].

\subsubsection{FTIR Analysis}

The FTIR spectra of neat and crosslinked pectin films are shown in Figure 1. The main functional groups were identified as carbomethoxy $\left(\mathrm{C}=\mathrm{O}, \sim 1740 \mathrm{~cm}^{-1}\right)$, methyl $\left(-\mathrm{CH}_{3}\right.$, $\sim 2938 \mathrm{~cm}^{-1}$ ), and carboxylate (COO- asymmetric and symmetric stretching vibration at $\sim 1630 \mathrm{~cm}^{-1}$ and $\sim 1437 \mathrm{~cm}^{-1}$ ) [31]. The intensity of the $\mathrm{C}=\mathrm{O},-\mathrm{CH}_{3}$, and COO-became higher with calcium concentrations, indicating that $\mathrm{Ca}^{2+}$ interacted with the $\mathrm{C}=\mathrm{O}$ group of pectin [32]. In addition, the increase in intensity may also be due to the electrostatic interactions between $\mathrm{Ca}^{2+}$ and $\mathrm{COO}-$ according to the "egg-box" model, and demonstrate that crosslinking occurred effectively $[27,33]$. 


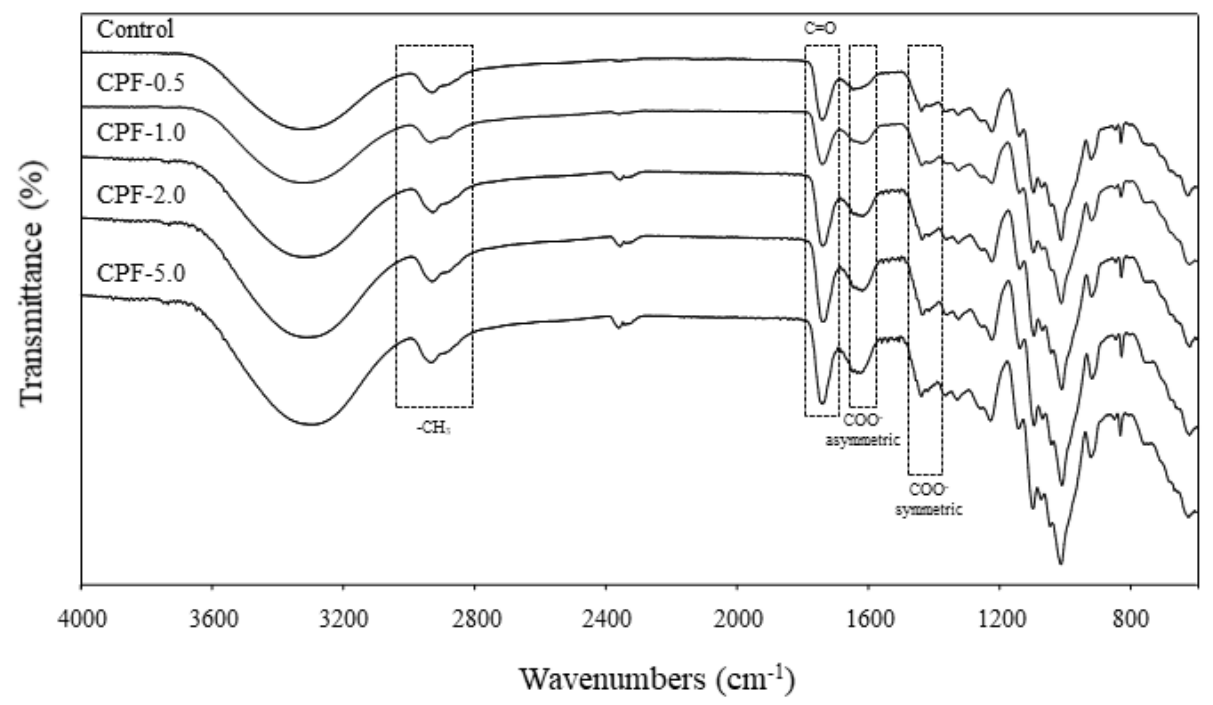

Figure 1. FTIR spectra of pure pectin film (control) and crosslinked pectin films (CPF) with 0.5, 1, 2, and $5 \% \mathrm{CaCl}_{2}$.

\subsection{Characterization of Crosslinked Pectin/ZnO Bionanocomposite Films \\ 3.2.1. Surface Color and Optical Properties}

Figure 2 shows the photographs of the crosslinked pectin film (CPF) and the crosslinked pectin/ ZnO bionanocomposite films (CPZBF) containing $0.5 \sim 1.5 \%$ ZnO-NPs. The appearance of the composite films changed to a more yellow color with increasing $\mathrm{ZnO}-\mathrm{NP}$ concentrations. The chromaticity of the bionanocomposite films is shown in Table 2. The control film (crosslinked pectin films without ZnO-NPs) was more transparent than the bionanocomposite films combined with $\mathrm{ZnO}-\mathrm{NPs}$. As expected, the total color difference $(\Delta E)$ in the bionanocomposite films increased with the addition of ZnO-NPs. As the content of $\mathrm{ZnO}$ increased, the $L$ and $a$ value decreased and the $b$ value increased significantly $(p<0.05)$, corresponding to a decrease in transparency and increase in yellowness. Control films exhibited $L, a$, and $b$ values of $93.3 \pm 0.6,-0.23 \pm 0.04$, and $6.31 \pm 0.67$, respectively. By contrast, the $L, a$, and $b$ values of the bionanocomposite film with $1.5 \% \mathrm{ZnO}-\mathrm{NPs}$ were $91.4 \pm 0.2,-0.34 \pm 0.03$, and $8.52 \pm 0.22$, respectively. These changes were reflected in the more intense dark green coloration of the bionanocomposite films as the ZnO-NP concentration increased. The increase in opacity resulting from the incorporation of $\mathrm{ZnO}-\mathrm{NPs}$ has been reported by other researchers $[9,34]$.

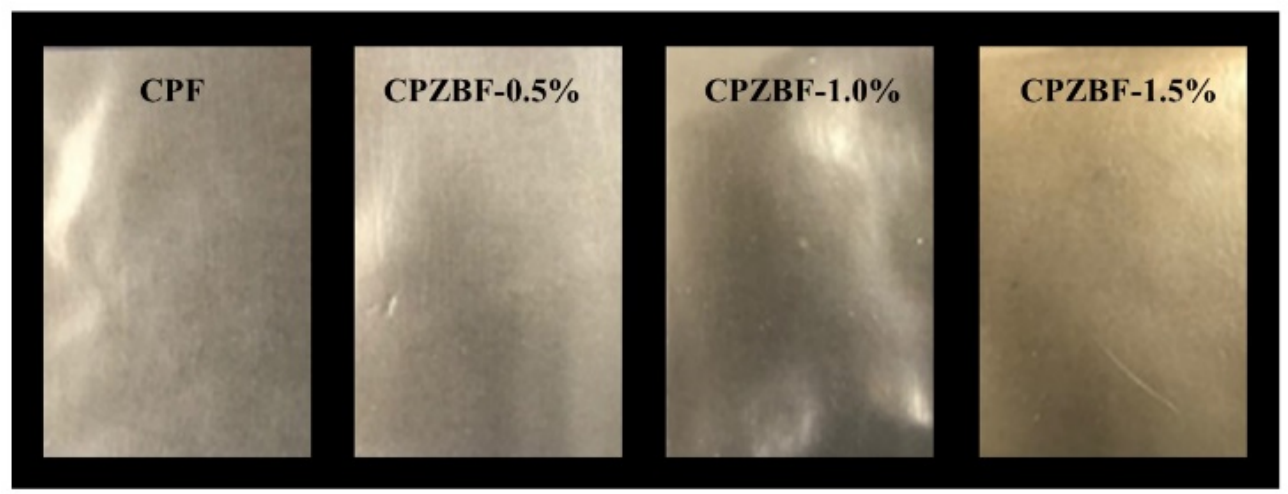

Figure 2. Photographs of the crosslinked pectin film (CPF) and the crosslinked pectin/ZnO bionanocomposite films (CPZBF) containing $0.5 \sim 1.5 \% \mathrm{ZnO}-\mathrm{NPs}$. 
Table 2. Effect of $\mathrm{ZnO}$ concentration on the surface color of the crosslinked pectin/ $\mathrm{ZnO}$ bionanocomposite films (CPZBF).

\begin{tabular}{ccccc}
\hline Sample $^{*}$ & $\boldsymbol{L}$ & $\boldsymbol{a}$ & $\boldsymbol{b}$ & $\boldsymbol{\Delta} \boldsymbol{E}$ \\
\hline CPF & $93.3 \pm 0.6^{\mathrm{c}}$ & $-0.23 \pm 0.04^{\mathrm{c}}$ & $6.31 \pm 0.67^{\mathrm{a}}$ & - \\
CPZBF-0.5\% & $92.1 \pm 0.6^{\mathrm{b}}$ & $-0.29 \pm 0.03^{\mathrm{b}}$ & $8.07 \pm 0.54^{\mathrm{b}}$ & $2.18 \pm 0.74^{\mathrm{a}}$ \\
CPZBF-1.0\% & $91.9 \pm 0.5^{\mathrm{b}}$ & $-0.36 \pm 0.03^{\mathrm{a}}$ & $8.16 \pm 0.54^{\mathrm{bc}}$ & $2.35 \pm 0.65^{\mathrm{a}}$ \\
CPZBF-1.5\% & $91.4 \pm 0.2^{\mathrm{a}}$ & $-0.34 \pm 0.03^{\mathrm{a}}$ & $8.52 \pm 0.22^{\mathrm{c}}$ & $2.96 \pm 0.25^{\mathrm{b}}$ \\
\hline
\end{tabular}

${ }^{*}$ Concentrations represent $\% \mathrm{ZnO}(w / w)$. Data represent the mean \pm standard deviation. Different letters in the same column indicate significant differences at $p<0.05$ by Duncan's multiple range test.

The UV barrier properties of the bionanocomposite films were evaluated by measuring their absorbance in the wavelength range of $200-550 \mathrm{~nm}$ (Figure 3). The absorbance of the bionanocomposite films increased after the incorporation of ZnO-NPs. Furthermore, two absorbance peaks were visible, including a sharp peak in the $280-300 \mathrm{~nm}$ region, which is characteristic of pectin [35], and a broad peak at approximately $360 \mathrm{~nm}$, corresponding to $\mathrm{ZnO}-\mathrm{NPs}$ [12]. The increase in UV absorbance as a result of $\mathrm{ZnO}$ incorporation agrees with previous reports $[18,34,36,37]$. The results obtained indicate that incorporating $\mathrm{ZnO}-\mathrm{NPs}$ into pectin improves the UV barrier properties of the resulting bionanocomposite films. Therefore, the developed bionanocomposite films could be used as UV-screening food packaging materials.

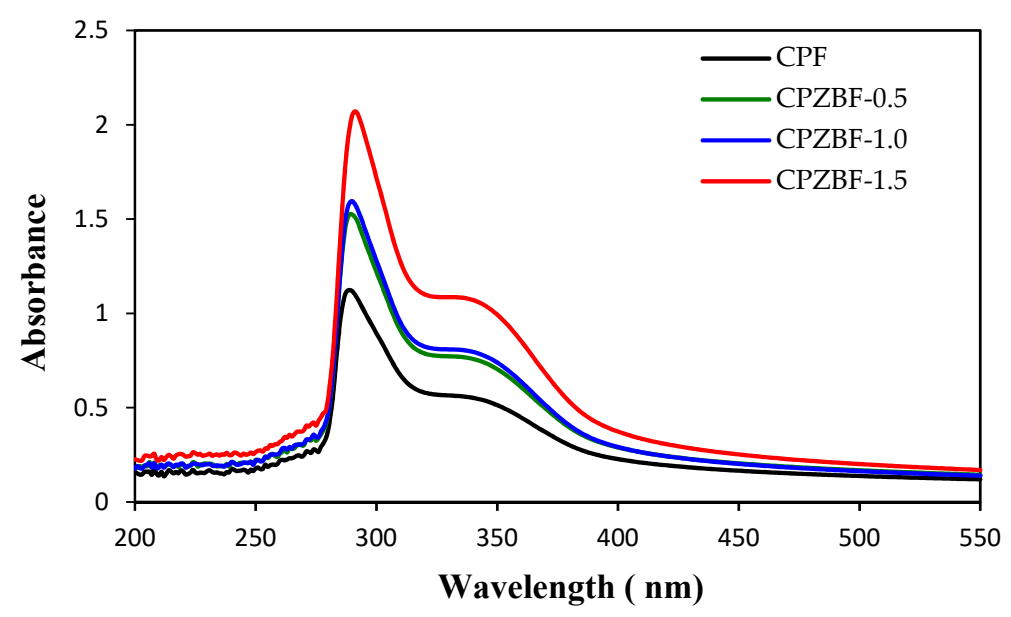

Figure 3. UV-visible spectra of crosslinked pectin film (CPF) and crosslinked pectin/ZnO bionanocomposite films (CPZBF) with $0.5,1$, and $1.5 \% \mathrm{ZnO}$ nanoparticles.

\subsubsection{Mechanical Properties}

Table 3 shows the effects of the ZnO-NP concentration on the thickness, YM, TS, and $E$ of the pectin/ZnO bionanocomposite films. Increasing the $\mathrm{ZnO}-\mathrm{NP}$ concentration did not have significant $(p>0.05)$ effects on the bionanocomposite film thickness. However, the TS was significantly $(p<0.05)$ increased from $22.7 \pm 1.4 \mathrm{MPa}$ for the control to $24.6 \pm 1.8 \mathrm{MPa}$ for the bionanocomposite film with $1.5 \% \mathrm{ZnO}-\mathrm{NPs}$. The Young's modulus also increased from $857.3 \pm 56.5 \mathrm{MPa}$ for the control to $899.4 \pm 65.8 \mathrm{MPa}$ for the nanocomposite with $1 \% \mathrm{ZnO}-\mathrm{NPs}$. On the other hand, $E$ tended to decrease as the $\mathrm{ZnO}-\mathrm{NP}$ content increased, from $6.1 \% \pm 1.0 \%$ for the control to $4.9 \% \pm 0.5 \%$ for the sample with $1.5 \% \mathrm{ZnO}-\mathrm{NPs}$. The bionanocomposite films developed here were stronger than pea starch $/ \mathrm{ZnO}$ nanocomposites (TS of 10.8 MPa) [37], although weaker than pectin/alginate/ $\mathrm{ZnO}$ nanocomposites (TS of 41.6 MPa) [34] and pectin/ ZnO nanocomposites incorporating 5\% ZnO-NPs (TS of 45.4 MPa) [9]. 
Table 3. Effect of $\mathrm{ZnO}$ concentration on the mechanical and water vapor barrier properties of the crosslinked pectin/ZnO bionanocomposite films (CPZBF).

\begin{tabular}{|c|c|c|c|c|c|}
\hline Sample * & $\begin{array}{l}\text { Thickness } \\
\qquad(\mu \mathrm{m})\end{array}$ & $\begin{array}{l}\text { Young's Modulus } \\
\text { (MPa) }\end{array}$ & $\begin{array}{c}\text { Tensile Strength } \\
\text { (MPa) }\end{array}$ & $\begin{array}{c}\text { Elongation at Break } \\
(\%)\end{array}$ & $\begin{array}{c}\text { WVP } \\
\left(\mathrm{mm} \cdot \mathrm{g} / \mathrm{m}^{2} \mathrm{kPa} \cdot \mathrm{h}\right)\end{array}$ \\
\hline $\mathrm{CPF}$ & $101.5 \pm 11.9^{a}$ & $857.3 \pm 56.5^{a b}$ & $22.7 \pm 1.4^{\mathrm{a}}$ & $6.05 \pm 1.01^{b}$ & $3.71 \pm 0.07^{\mathrm{a}}$ \\
\hline CPZBF-0.5\% & $97.9 \pm 13.9^{\mathrm{a}}$ & $838.8 \pm 70.4^{a}$ & $24.1 \pm 2.2^{\mathrm{ab}}$ & $5.92 \pm 0.89^{b}$ & $3.45 \pm 0.09^{a}$ \\
\hline CPZBF-1.0\% & $95.4 \pm 15.6^{\mathrm{a}}$ & $884.0 \pm 48.4^{b}$ & $24.4 \pm 2.1^{b}$ & $4.94 \pm 0.65^{\mathrm{a}}$ & $3.56 \pm 0.08^{a b}$ \\
\hline CPZBF-1.5\% & $106.0 \pm 13.2^{\mathrm{a}}$ & $899.4 \pm 65.8^{b}$ & $24.6 \pm 1.8^{b}$ & $4.87 \pm 0.49^{a}$ & $3.63 \pm 0.14^{\mathrm{ab}}$ \\
\hline
\end{tabular}

${ }^{*}$ Concentrations represent $\% \mathrm{ZnO}(w / w)$. Data represent the mean \pm standard deviation. Different letters in the same column indicate significant differences at $p<0.05$ by Duncan's multiple range test.

The mechanical properties of bionanocomposite films can be influenced by several factors, including the dispersion of the nanofillers and nanofiller-matrix interactions [37]. Some studies agree with the observed increase in TS as a result of the incorporation of ZnO-NPs [33,36]; however, the opposite effect was reported for nanocomposites based on agar, carrageenan, carboxymethyl cellulose, and gelatin $[18,36]$.

The increase in TS observed here suggests that $\mathrm{Zn}^{2+}$ binds to the hydroxyl $\left(\mathrm{OH}^{-}\right)$ and carboxylate $\left(\mathrm{COO}^{-}\right)$groups of pectin chains in a similar way as that described in the "egg-box" model, although $\mathrm{Ca}^{2+}$ is reported to interact only with carboxylate groups [38]. The effectiveness of the reinforcement material and its dispersion in the polymer matrix are crucial for effective stress transfer at the matrix-nanofiller interface, and ultimately increase the TS of polymeric biocomposite materials, although the trade-off is a decrease in elasticity $[39,40]$. The TS of the bionanocomposite films developed is comparable to that of polypropylene and ethylene-polypropylene (26 MPa), although their $E$ is substantially lower than that of most other polymers used in packaging except polystyrene (1.6\%) [41]. Thus, further improvements in the mechanical properties of the bionanocomposite films are necessary.

\subsubsection{Water Vapor Permeability (WVP)}

The WVP of the bionanocomposite films is shown in Table 3. No significant $(p>0.05)$ changes in the WVP of the films were observed, suggesting that the incorporation of ZnO-NPs did not affect the water affinity of the pectin-based bionanocomposite films. This result may be due to the high hydrophilicity of pectin, the low concentration of $\mathrm{ZnO}$ NPs incorporated into the films, and the high concentration of glycerol used to prepare them, as it has been reported that glycerol may increase the spacing between polymer chains, enabling the passage of water vapor [29]. The WVP obtained here is higher than that of synthetic plastics as well as pure hydroxypropyl methylcellulose films [24], which are known for their hydrophilicity, and thus indicates that decreasing the WVP of the pectin/ZnO bionanocomposite films remains a challenge.

\subsubsection{DSC Analysis}

The DSC thermograms of the crosslinked pectin film and pectin/ZnO bionanocomposite films are shown in Figure 4. Only small changes were observed in the thermograms, suggesting that $\mathrm{ZnO}$ incorporation only slightly improved the thermal resistance of the films. This may be explained by the low concentration of $\mathrm{ZnO}$ incorporated [42]. The thermograms of the crosslinked pectin film (CPF) showed two endotherms, one at around $110{ }^{\circ} \mathrm{C}$ and the other at around $180{ }^{\circ} \mathrm{C}$. These temperatures increased to 115 and $190{ }^{\circ} \mathrm{C}$, respectively, for the bionanocomposite film with 1.5\% $\mathrm{ZnO}$ (CPZBF-1.5). The first endotherm represents the glass transition temperature $\left(\mathrm{T}_{\mathrm{g}}\right)$ of the film and is associated with water loss, whereas the second one represents the melting temperature $\left(\mathrm{T}_{\mathrm{m}}\right)$ of the film $[43,44]$. In addition, an exothermic peak was observed at around $245^{\circ} \mathrm{C}$ for the bionanocomposite film with $1.5 \% \mathrm{ZnO}\left(240{ }^{\circ} \mathrm{C}\right.$ for the crosslinked pectin film). This peak represents the thermal depolymerization of pectin [45] and, as the results show, the addition of $\mathrm{ZnO}$ hindered the degradation of the polymer, albeit slightly. 


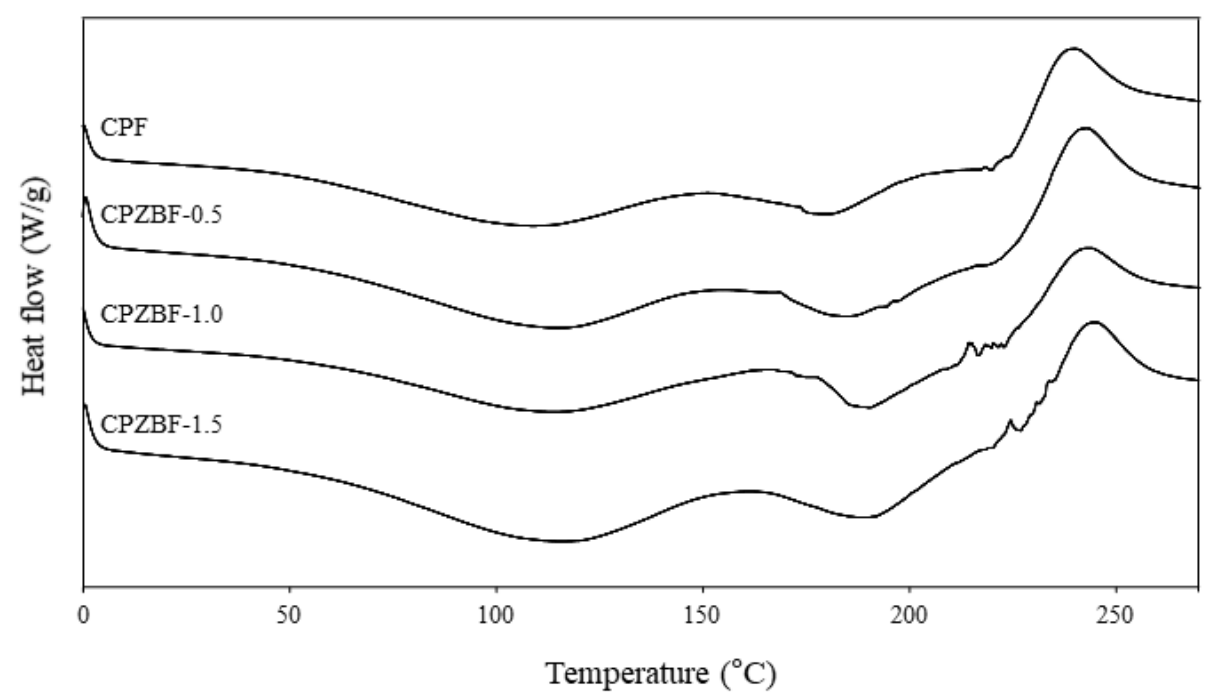

Figure 4. DSC thermograms of crosslinked pectin film (CPF) and crosslinked pectin/ZnO bionanocomposite films (CPZBF).

\subsubsection{Antibacterial Activity}

The antibacterial activity of the bionanocomposite films against E. coli and S. aureus is shown in Table 4 and Figure 5. The bionanocomposite films showed antibacterial activity against both $E$. coli and S. aureus, although their effectiveness was slightly greater against the latter. Other studies have also reported the stronger antimicrobial effects of ZnO-NPs against Gram-positive bacteria $[18,36]$. Moreover, antifungal effects of ZnO-NPs were also reported [9]. The antibacterial activity of the bionanocomposite films increased significantly $(p<0.05)$ with an increase in the concentration of ZnO-NPs, with the bionanocomposite film containing $1.5 \% \mathrm{ZnO}$ showing the greatest antibacterial rate (>99\%) against both strains. At this concentration, the antibacterial activity was $2.04 \pm 0.04$ and $2.11 \pm 0.05$ for E. coli and S. aureus, respectively, indicating that the films were effective according to the Z2801:2010 regulation, which requires a minimum antibacterial activity of 2.0 [26].

Table 4. Antibacterial rate and activity of the crosslinked pectin/ZnO bionanocomposite films (CPZBF) against E. coli and S. aureus.

\begin{tabular}{ccccc}
\hline \multirow{2}{*}{ Sample * $^{*}$} & \multicolumn{2}{c}{ E. coli } & \multicolumn{2}{c}{ S. aureus } \\
\cline { 2 - 5 } & $\begin{array}{c}\text { Antibacterial } \\
\text { Rate (\%) }\end{array}$ & $\begin{array}{c}\text { Antibacterial } \\
\text { Activity }\end{array}$ & $\begin{array}{c}\text { Antibacterial } \\
\text { Rate (\%) }\end{array}$ & $\begin{array}{c}\text { Antibacterial } \\
\text { Activity }\end{array}$ \\
\hline CPF & $1.9 \pm 0.2^{\mathrm{a}}$ & $0.01 \pm 0.01^{\mathrm{a}}$ & $0.9 \pm 0.5^{\mathrm{a}}$ & $0.00 \pm 0.01^{\mathrm{a}}$ \\
CPZBF-0.5 & $94.1 \pm 0.4^{\mathrm{b}}$ & $1.23 \pm 0.03^{\mathrm{b}}$ & $96.1 \pm 0.3^{\mathrm{b}}$ & $1.41 \pm 0.03^{\mathrm{b}}$ \\
CPZBF-1.0 & $98.2^{\mathrm{b}} \pm 0.2^{\mathrm{c}}$ & $1.74 \pm 0.05^{\mathrm{c}}$ & $99.0 \pm 0.1^{\mathrm{c}}$ & $1.98 \pm 0.05^{\mathrm{c}}$ \\
CPZBF-1.5 $^{\mathrm{c}}$ & $99.1 \pm 0.1^{\mathrm{c}}$ & $2.04 \pm 0.04^{\mathrm{d}}$ & $99.2 \pm 0.1^{\mathrm{c}}$ & $2.11 \pm 0.05^{\mathrm{d}}$ \\
\hline
\end{tabular}

${ }^{*}$ Concentrations represent $\% \mathrm{ZnO}(w / w)$. Data represent the mean \pm standard deviation. Different letters in the same column indicate significant differences at $p<0.05$ by Duncan's multiple range test.

The antibacterial properties of $\mathrm{ZnO}-\mathrm{NPs}$ have been reported by other researchers $[18,36,42,46]$. The antibacterial activity of ZnO-NPs appears to be due to the release of $\mathrm{Zn}^{2+}$ ions, which penetrate the cell wall of bacteria, killing them. Because Gram-positive bacteria have a thick cell wall to which ZnO-NPs can bind, they are more susceptible to these antibacterial effects. $\mathrm{ZnO}-\mathrm{NPs}$ can also generate reactive oxygen species (ROS) such as hydrogen peroxide $\left(\mathrm{H}_{2} \mathrm{O}_{2}\right)$, which damage the cell membrane of bacteria [47]. It is assumed that both the production of ROS and the deposition of $\mathrm{Zn}^{2+}$ ions within the cytoplasm lead to either the inhibition or killing of bacterial cells [20,48]. Thus, the films developed in this study could be applied as wrapping to hinder bacteria and extend the shelf life of fresh produce, as reported in the literature for similar films [7]. Considering the 
lower mechanical and water barrier properties of pectin films compared to polymers commonly used in packaging, another strategy to be considered would be to incorporate these films into multilayer structures, aiming to provide specific functions, namely antimicrobial effects and UV-barrier properties, to the packaging $[15,20]$.

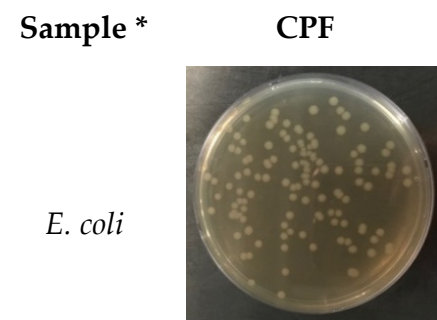

Dilution factor $10^{3}$

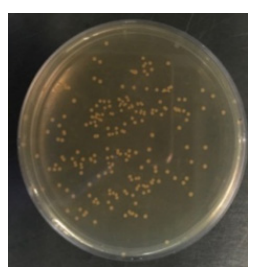

Dilution factor $10^{3}$
CPZBF-0.5

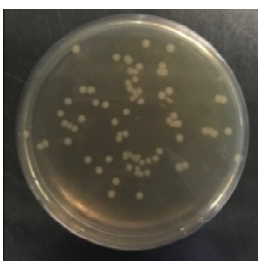

Dilution factor $10^{2}$

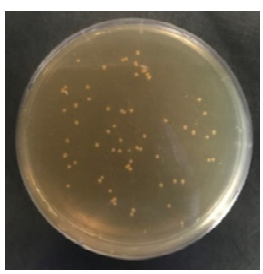

Dilution factor $10^{2}$
CPZBF-1.0

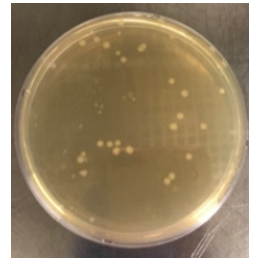

Dilution factor $10^{2}$

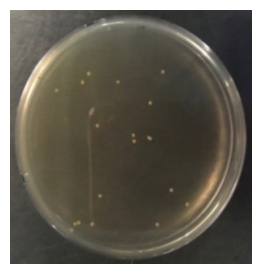

Dilution factor $10^{2}$
CPZBF-1.5

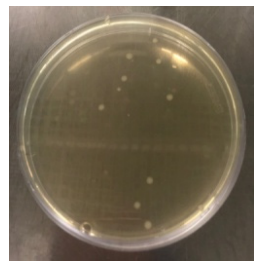

Dilution factor $10^{2}$

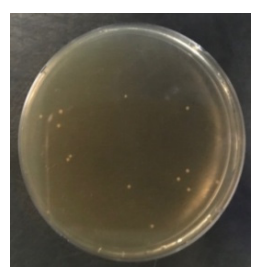

Dilution factor $10^{2}$

Figure 5. Colony forming units (CFU) of E. coli and S. aureus after exposure to crosslinked pectin film $(\mathrm{CPF})$ and crosslinked pectin/ZnO bionanocomposite films (CPZBF). ${ }^{*}$ Concentrations represent \% $\mathrm{ZnO}(w / w)$.

\section{Conclusions}

Crosslinked pectin films showed greater tensile strength than did pure pectin films, although their elongation at break was lower. FTIR analysis revealed the interaction between pectin and $\mathrm{CaCl}_{2}$ and confirmed the formation of crosslinking. Adding $\mathrm{ZnO}-\mathrm{NPs}$ to the crosslinked pectin films significantly improved their UV barrier and mechanical properties, resulting in stronger bionanocomposite films able to block UV irradiation, although the trade-off of this outcome was darkening and loss of flexibility. In addition, the crosslinked pectin/ $\mathrm{ZnO}$ bionanocomposite films exhibited strong antibacterial activity against food-borne pathogenic bacteria such as E. coli and S. aureus. Therefore, the developed bionanocomposite films show potential to be used as active food packaging with antibacterial and UV-light barrier properties.

Author Contributions: K.D.H.: conceptualization, methodology, software, validation, formal analysis, investigation, writing—original draft; C.V.G.: writing—original draft, writing-review and editing; G.-H.S.: writing — review and editing; J.-T.K.: conceptualization and supervision, writingreview and editing. All authors have read and agree to the published version of the manuscript.

Funding: This research received no external funding.

Data Availability Statement: All the data will be available to the readers.

Acknowledgments: This research was supported by the Keimyung University Research Grant of 2020 .

Conflicts of Interest: The authors declare no conflict of interest. 


\section{References}

1. Jo, Y.; Garcia, C.V.; Ko, S.; Lee, W.; Shin, G.H.; Choi, J.C.; Park, S.J.; Kim, J.T. Characterization and antibacterial properties of nanosilver-applied polyethylene and polypropylene composite films for food packaging applications. Food Biosci. 2018, 23, 83-90. [CrossRef]

2. Neira, L.M.; Agustinelli, S.P.; Ruseckaite, R.A.; Martucci, J.F. Shelf life extension of refrigerated breaded hake medallions packed into active edible fish gelatin films. Packag. Technol. Sci. 2019, 32, 1-10. [CrossRef]

3. Duncan, T.V. Application of nanotechnology in food packaging and food safety: Barrier materials, antimicrobials and sensors. J. Colloid Interface Sci. 2011, 363, 1-24. [CrossRef] [PubMed]

4. Rhim, J.W.; Park, H.M.; Ha, C.S. Bio-nanocomposites for food packaging applications. Prog. Polym. Sci. 2013, 38, 1629-1652. [CrossRef]

5. Kim, J.T.; Netravali, A.N. Physical properties of biodegradable films of soy protein concentrate/gelling agent blends. Macromol. Mater. Eng. 2012, 297, 176-183. [CrossRef]

6. Laurent, M.A.; Boulenguer, P. Stabilization mechanism of acid dairy drinks (ADD) induced by pectin. Food Hydrocoll. 2003, 17, 445-454. [CrossRef]

7. Mellinas, C.; Ramos, M.; Jiménez, A.; Garrigós, M.C. Recent trends in the use of pectin from agro-waste residues as a natural-based biopolymer for food packaging applications. Materials 2020, 13, 673. [CrossRef]

8. Aldana, D.S.; Andrade-Ochoa, S.; Aguilar, C.N.; Contreras-Esquivel, J.C.; Nevárez-Moorillón, G.V. Antibacterial activity of pectic-based edible films incorporated with Mexican lime essential oil. Food Control 2015, 50, 907-912. [CrossRef]

9. Suyatma, N.E.; Ishikawa, Y.; Kitazawa, H. Nanoreinforcement of pectin film to enhance its functional packaging properties by incorporating $\mathrm{ZnO}$ nanoparticles. Adv. Mat. Res. 2014, 845, 451-456. [CrossRef]

10. Chaichi, M.; Hashemi, M.; Badii, F.; Mohammadi, A. Preparation and characterization of a novel bionanocomposite edible film based on pectin and crystalline nanocellulose. Carbohydr. Polym. 2017, 157, 167-175. [CrossRef] [PubMed]

11. Al-Asmar, A.; Giosafatto, C.V.L.; Sabbah, M.; Sanchez, A.; Santana, R.V.; Mariniello, L. Effect of mesoporous silica nanoparticles on the physicochemical properties of pectin packaging material for strawberry wrapping. Nanomaterials 2020, 10, 52. [CrossRef] [PubMed]

12. Sucheta; Chaturvedi, K.; Sharma, N.; Yadav, S.K. Composite edible coatings from commercial pectin, corn flour and beetroot powder minimize post-harvest decay, reduces ripening and improves sensory liking of tomatoes. Int. J. Biol. Macromol. 2019, 133, 284-293. [CrossRef]

13. Rodsamran, P.; Sothornvit, R. Lime peel pectin integrated with coconut water and lime peel extract as a new bioactive film sachet to retard soybean oil oxidation. Food Hydrocoll. 2019, 97, 105173. [CrossRef]

14. da Silva, I.S.V.; de Sousa, R.M.F.; de Oliveira, A.; de Oliveira, W.J.; Motta, L.A.C.; Pasquini, D.; Otaguro, H. Polymeric blends of hydrocolloid from chia seeds/apple pectin with potential antioxidant for food packaging applications. Carbohydr. Polym. 2018, 202, 203-210. [CrossRef] [PubMed]

15. Balik, B.A.; Argin, S.; Lagaron, J.M.; Torres-Giner, S. Preparation and characterization of electrospun pectin-based films and their application in sustainable aroma barrier multilayer packaging. Appl. Sci. 2019, 9, 5136. [CrossRef]

16. Azeredo, H.M.C.; Waldron, K.W. Crosslinking in polysaccharide and protein films and coatings for food contact-A review. Trends Food Sci. Technol. 2016, 52, 109-122. [CrossRef]

17. Fraeye, I.; Duvetter, T.; Doungla, E.; Loey, A.V.; Hendrickx, M. Fine-tuning the properties of pectin-calcium gels by control of pectin fine structure, gel composition and environmental conditions. Trends Food Sci. Technol. 2010, 21, 219-228. [CrossRef]

18. Shankar, S.; Teng, X.; Li, G.; Rhim, J.W. Preparation, characterization, and antimicrobial activity of gelatin/ZnO nanocomposite films. Food Hydrocoll. 2015, 45, 264-271. [CrossRef]

19. Marcous, A.; Rasouli, S.; Ardestani, F. Low-density polyethylene films loaded by titanium dioxide and zinc oxide nanoparticles as a new active packaging system against Escherichia coli O157:H7 in fresh calf minced meat. Packag. Technol. Sci. 2017, 30, 693-701. [CrossRef]

20. Espitia, P.J.P.; Soares, N.dF.F.; Coimbra, J.S.dR.; de Andrade, N.J.; Cruz, R.S.; Medeiros, E.A.A. Zinc oxide nanoparticles: Synthesis, antimicrobial activity and food packaging applications. Food Bioprocess Technol. 2012, 5, 1447-1464. [CrossRef]

21. Garcia, C.V.; Shin, G.H.; Kim, J.T. Metal oxide-based nanocomposites in food packaging: Applications, migration, and regulations. Trends Food Sci. Technol. 2018, 82, 21-31. [CrossRef]

22. American Society for Testing and Material. Standard Test Method for Tensile Properties of Thin Plastic Sheeting; American Society for Testing and Material: West Conshohocken, PA, USA, 2012.

23. Hosseini, M.H.; Razavi, S.H.; Mousavi, M.A. Antimicrobial, physical and mechanical properties of chitosan-based films incorporated with thyme, clove and cinnamon essential oils. J. Food Process Preserv. 2009, 33, 727-743. [CrossRef]

24. Lee, J.Y.; Garcia, C.V.; Shin, G.H.; Kim, J.T. Antibacterial and antioxidant properties of hydroxypropyl methylcellulose-based active composite films incorporating oregano essential oil nanoemulsions. LWT 2019, 106, 164-171. [CrossRef]

25. Nisar, T.; Wang, Z.C.; Yang, X.; Tian, Y.; Iqbal, M.; Guo, Y. Characterization of citrus pectin films integrated with clove bud essential oil: Physical, thermal, barrier, antioxidant and antibacterial properties. Int. J. Biol. Macromol. 2018, 106, 670-680. [CrossRef]

26. Japanese Industrial Standard. Antimicrobial Products: Test for Antimicrobial Activity and Efficacy; Japanese Industrial Standard: Tokyo, Japan, 2010. 
27. Braccini, I.; Pérez, S. Molecular basis of $\mathrm{Ca}^{2+}$ - induced gelation in alginates and pectins: The egg box model revisited. Biomacromolecules 2001, 2, 1089-1096. [CrossRef]

28. Pavlath, A.E.; Voisin, A.; Robertson, G.H. Pectin-based biodegradable water insoluble films. Macromol. Symp. 1999, 140, 107-113. [CrossRef]

29. Seixas, F.L.; Turbiani, F.R.B.; Salomão, P.G.; Souza, R.P.; Gimenes, M.L. Biofilms composed of alginate and pectin: Effect of concentration of crosslinker and plasticizer agents. Chem. Eng. Trans. 2013, 32, 1693-1698.

30. Garavand, F.; Rouhi, M.; Razavi, S.H.; Cacciotti, I.; Mohammadi, R. Improving the integrity of natural biopolymer films used in food packaging by crosslinking approach: A review. Int. J. Biol. Macromol. 2017, 104, 687-707. [CrossRef]

31. Guo, X.; Duan, H.; Wang, C.; Huang, X. Characteristics of two calcium pectinates prepared from citrus pectin using either calcium chloride or calcium hydroxide. J. Agric. Food Chem. 2014, 62, 6354-6361. [CrossRef]

32. Nurjaya, S.; Wong, T.W. Effects of microwave on drug release properties of matrices of pectin. Carbohydr. Polym. 2005, 62, 245-257. [CrossRef]

33. Thibault, J.F.; Rinaudo, M. Chain association of pectic molecules during calcium-induced gelation. Biopolymers 1986, 25, 455-468. [CrossRef]

34. Ngo, T.M.P.; Dang, T.M.Q.; Tran, T.X.; Rachtanapun, P. Effects of zinc oxide nanoparticles on the properties of pectin/alginate edible films. Int. J. Polym. Sci. 2018, 2018, 5645797. [CrossRef]

35. Shankar, S.; Tanomrod, N.; Rawdkuen, S.; Rhim, J.W. Preparation of pectin/silver nanoparticles composite films with UV-light barrier and properties. Int. J. Biol. Macromol. 2016, 92, 842-849. [CrossRef] [PubMed]

36. Kanmani, P.; Rhim, J.W. Properties and characterization of bionanocomposite films prepared with various biopolymers and $\mathrm{ZnO}$ nanoparticles. Carbohydr. Polym. 2014, 106, 190-199. [CrossRef] [PubMed]

37. Ma, X.; Chang, P.R.; Yang, J.; Yu, J. Preparation and properties of glycerol plasticized-pea starch/zinc oxide-starch bionanocomposites. Carbohydr. Polym. 2009, 75, 472-478. [CrossRef]

38. Assifaoui, A.; Lerbret, A.; Uyen, H.T.D.; Neiers, F.; Chambin, O.; Loupiac, C.; Cousin, F. Structural behaviour differences in low methoxy pectin solutions in the presence of divalent cations $\left(\mathrm{Ca}^{2+}\right.$ and $\left.\mathrm{Zn}^{2+}\right)$ : A process driven by the binding mechanism of the cation with the galacturonate unit. Soft Matter 2015, 11, 551-560. [CrossRef] [PubMed]

39. Díez-Pascual, A.M.; Díez-Vicente, A.L. ZnO-reinforced poly(3-hydroxybutyrate-co-3-hydroxyvalerate) bionanocomposites with antimicrobial function for food packaging. ACS Appl. Mater. Interfaces 2014, 6, 9822-9834. [CrossRef] [PubMed]

40. Ahmed, J.; Arfat, Y.A.; Castro-Aguirre, E.; Auras, R. Mechanical, structural and thermal properties of Ag-Cu and ZnO reinforced polylactide nanocomposite films. Int. J. Biol. Macromol. 2016, 86, 885-892. [CrossRef]

41. Crompton, T.R. Physical Testing of Plastics; Smithers Rapra Technology: Ravenna, OH, USA, 2012 ; pp. 1-134.

42. Shankar, S.; Wang, L.F.; Rhim, J.W. Incorporation of zinc oxide nanoparticles improved the mechanical, water vapor barrier, UV-light barrier, and antibacterial properties of PLA-based nanocomposite films. Mat. Sci. Eng. C 2018, 93, 289-298. [CrossRef]

43. Mishra, R.K.; Sutar, P.B.; Singhal, J.P.; Banthia, A.K. Graft copolymerization of pectin with polyacrylamide. Polym. Plast. Technol. Eng. 2007, 46, 1079-1085. [CrossRef]

44. Einhorn-Stoll, U.; Kunzek, H.; Dongowski, G. Thermal analysis of chemically and mechanically modified pectins. Food Hydrocoll. 2007, 21, 1101-1112. [CrossRef]

45. Shi, L.; Gunasekaran, S. Preparation of pectin-ZnO nanocomposite. Nanoscale Res. Lett. 2008, 3, 491-495. [CrossRef]

46. Li, J.H.; Hong, R.Y.; Li, M.Y.; Li, H.Z.; Zheng, Y.; Ding, J. Effects of ZnO nanoparticles on the mechanical and antibacterial properties of polyurethane coatings. Prog. Org. Coat. 2009, 64, 504-509. [CrossRef]

47. Tayel, A.A.; El-Tras, W.F.; Moussa, S.; El-Baz, A.F.; Mahrous, H.; Salem, M.F.; Brimer, L. Antibacterial action of zinc oxide nanoparticles against foodborne pathogens. J. Food Saf. 2011, 31, 211-218. [CrossRef]

48. Zhang, L.; Jiang, Y.; Ding, Y.; Daskalakis, N.; Jeuken, L.; Povey, M.; O’Neill, A.J.; York, D.W. Mechanistic investigation into antibacterial behavior of suspensions of $\mathrm{ZnO}$ nanoparticles against E. coli. J. Nanopart. Res. 2010, 12, 1625-1636. [CrossRef] 